\title{
4. LOWER CRETACEOUS FORAMINIFERAL BIOSTRATIGRAPHY, PALEOECOLOGY, AND DEPOSITIONAL ENVIRONMENT AT DSDP SITE 397, LEG 47A
}

\author{
Arif Butt, Institut für Geologie und Paläontologie, Universität Tübingen, Federal Republic of Germany
}

\begin{abstract}
Biostratigraphic results of foraminiferal studies for Site 397 indicate a probable Hauterivian-Barremian through BarremianAptian age for the Lower Cretaceous sedimentary section (Unit 5, Cores 52A-35A). Typical index species of the planktonic foraminifers include Hedbergella hoterivica, Hedbergella sigali, Calvihedbergella aff. simplex, and Globigerinelloides blowi. Important benthic species include Epistomina caracolla, Epistomina hechti, Epistomina cretosa, Epistomina ornata, Lenticulina nodosa, Lenticulina saxonica, Lenticulina praegaultina, Lenticulina heiermanni, Lenticulina matilatus, and Conorboides sp. Sedimentologic and ecologic data from the microfossils suggest prodelta shelf depth merging into upper bathyal environments. Benthic foraminifers (such as Quinqueloculina associated with ostracodes and small gastropods and pelecypods) may indicate a nearshore environment in front of a deltaic complex. Epistominids (such as Epistomina caracolla and the nodosariids such as Lenticulina, Dentalina, and Planularia) indicate an outer-shelf to upper bathyal environment. However, hedbergellids and a few radiolarian specimens suggest the epipelagic setting of an open-shelf water mass, and can be compared with Recent shelf pelagic biota. Paucity of fauna indicates neither stagnant bottom conditions (pelagic sapropel) nor oceanic depths below the calcite compensation depth (CCD). The barren character of the facies may indicate dilution by the sediments due to continuous terrigenous (cyclic sedimentation) input into the shelf basin. This in turn caused instability of the biophysiochemical conditions. Scarcity of the pelagic constituents in the sediment may also reflect low plankton productivity, possibly related to a restricted circulation due to the paleogeographic setting of the macroplates during the Early Cretaceous.
\end{abstract}

\section{INTRODUCTION}

During Leg 47A, Site 397 was drilled on the uppermost continental rise offshore from Cape Bojador. One of the main objectives at this site was to reconstruct the geologic history and evolution of the passive continental margin in the eastern North Atlantic during the Mesozoic. Through continuous drilling, about 1453 meters of sedimentary section were recovered at a water depth of 2900 meters nearly $100 \mathrm{~km}$ offshore from the TarfayaAaiun coastal region. The lower part of the sedimentary section $(153 \mathrm{~m})$ is mainly of Barremian age and is separated from the Neogene at 1300 meters by a large hiatus (approximately Aptian-earliest Miocene). In this report, only the Cretaceous part of the section (Cores 52 to 34 of Hole 397A) is discussed. This section is defined lithologically as Unit 5 (see Site Report, this volume) and consists mainly of hemipelagic laminated strata consisting of fine-grained gray greenish to dark gray silty mudstones with occasional dolomitic and sideritic intercalation (Einsele and von Rad, this volume). Microfossils such as foraminifers are rare, and several samples are completely barren. The scarcity of fauna has been explained by stagnation of the bottom waters or by deposition below the CCD (Einsele and von Rad; Basov et al.; Roesler et al.; all this volume). The ecologic interpretations made in this report (which are based on a study of 150 samples from Cores 52 to 34 of Hole 397A) do not favor either of these views. Important disagreements also exist concerning the exact biostratigraphic position of the Lower Cretaceous sediments at Site 397 (see Site Report, this volume). On the basis of nannoplankton ranges, Čepek and Wind (this volume) propose a middle-late Hauterivian age, while Basov et al. (this volume) and Wiedmann (this volume) suggest Barremian-Aptian and Hauterivian-Barremian ages, respectively, on the basis of studying foraminifers and ammonites. However, the biostratigraphic results of this study support the views of Basov et al. and Wiedmann. However, three fundamental differences do exist: (1) disagreement of foraminiferal and nannoplankton results in general, (2) first appearance of the 
genus Favusella and its association to pre-Albian planktonic foraminifers such as Hedbergella hoterivica, (3) the lack of an SEM study of the type specimens of Hedbergella hotervica.

Because of the above conflicting results about Unit 5, the author has attempted to present a synthesis by comparing the sediments at Site 397 with the onshore Creataceous sections in the Tarfaya-Aaiun and AgadirEssaouira regions of northwestern Africa.

\section{BIOSTRATIGRAPHY}

\section{Results}

Between 2 and 3 samples per section of Cores 52 to 34 of Hole 397A were analyzed to study their foraminiferal composition. Unfortunately, most of the samples were found to be barren, consisting mainly of terrigenous quartz and subordinate mica and pyrite grains. Plant fragments were common in the washed sample residue. In sections 47-1, 46-3, 46-2, and 42-2 (Figure 1) maximum numbers (30 to 50 specimens per sample), of microfossils including foraminifers, ostracodes, pelecypods, gastropods, radiolarians, and fish debris. The abundance of microfossils roughly correlates with the relative abundance of calcium carbonate in the cores (see Site Report, this volume). Foraminifers are generally small, but nodosariids such as Lenticulina display a normal size and moderately high diversity. Planktonic foraminifers include small fragile primitive "globigerine forms," placed here under the genus Hedbergella, although some specimens of the genus Globigerinelloides could also be identified. The planktonic specimens are generally well preserved, but some show diagenetic corrosion of the shell wall. Furthermore, the faunas do not show any sign of reworking or hydrodynamic sorting. Stratigraphic ranges of the foraminifers and other microfossils in Cores 52 to 34 of Hole 397A are shown in Figure 1, while typical representative specimens are figured in Plates 1 to 4.

\section{Discussion of Results}

Hedbergella hoterivica (Ascoli, 1976, renamed it as Caucasella hoterivica; synonomy Globigerina kugleri Bolli) in Hole 397A first appears in Sample 51 A-1, 29-35 $\mathrm{cm}$; while Epistomina carocolla first occurs in Sample 52A-2, 6-10 cm; Epistomina cretosa in Sample 50A-5, 21-25 cm; and Epistomina hechti and Lenticulina saxonica in Sample 50A-4, 95-100 cm. These suggest a Hauterivian-Barremian age. Supporting evidence for lowermost Barremian in Sample 50A-2, 0-6 cm comes with the occurrence of Epistomina hechti (aff. Epistomina spinulifera), Lenticulina nodosa, Lenticulina praegaultina, and Conorbiodes sp. This assemblage, along with Hedbergella hoterivica and Epistomina caracolla, may suggest the Barremian-Hauterivian boundary in Core 50A (Figure 1 and Plates 1 to 4 ).

The presence of Lenticulina heiermanni in Sample 47A-4, 51-55 cm; Lenticulina matilatus and Lenticulina sp. 1 in Sample 46-3, 145-149 cm; and Hedbergella sigali, Clavihedbergella aff. simplex, Globigerinelloides blowi, and Hedbergella hoterivica in Sample 46-2, 101-105 cm confirms the Barremian age of Cores 50 to 46 in Hole 397A. This conclusion agrees with van Hinte's (1976) zonal scheme of the Cretaceous. Similar species from land deposits are described by several authors (Subbotina, 1953; Bolli, 1959; Moullade, 1966; Fuchs, 1971). Hedbergella hoterivica, Hedbergella sigali, Clavihedbergella aff. simplex, Globigerinelloides blowi, and a single specimen of Frondicularia sp. were identified again in Section 42-2 (Plates 1-4). In contrast to Cores 47,46 , and 42 of Hole $397 \mathrm{~A}$, Cores 41 to 35 contain very rare specimens of Hedbergella hoterivica and Epistomina caracolla, while Core 34 is contaminated throughout by Tertiary foraminifers. Sample $42-2,5-10 \mathrm{~cm}$ consists of relatively abundant and diverse post-Hauterivian planktonic species (nearly 30 specimens). The relative abundance of Hedbergella sigali and Globigerinelloides blowi may suggest a BarremianAptian age for Cores 42 to 35 . Due to the extreme contamination of Core 34, no age designation can be made.

Bolli (1959) described Globigerinelloides blowi as Planomalina blowi from ?Barremian-Aptian and Globigerina kugleri (synonomy of Hedbergella hoterivica) from Barremian-Aptian sediments in Trinidad. Globigerina hoterivica, identified here as a species of the genus Hedbergella, was originally described by Subbotina (1953) from upper Hauterivian sediments in the northern Caucasus. Ascoli (1976) mentioned the same species as Caucasella hoterivica from the ValanginianBarremian sediments in the Scotian Shelf of the western North Atlantic. Thus, the occurrence of Hedbergella hoterivica can be correlated on both sides of the North Atlantic. Thus the Lower Cretaceous benthic foraminifers, similar to the planktonics, indicate an identical ecologic niche in both eastern and western realms of the North Atlantic (Ascoli, 1976; Bartenstein, 1976; Butt in Wiedmann et al., 1978).

Daily (1973) described Hedbergella hoterivica as Globigerina hoterivica from Hauterivian-Barremian sediments in the Sacramento Valley of California, while Michael (1967) and Fuchs (1971) identified it in Barremian sediments in northwestern Germany and Vorarlberg (Austria), respectively. However, Dailey mentioned that some of these specimens of Hedbergella hoterivica show coarse perforations. It is still unknown whether these perforations in the shell wall of Dailey's specimens correspond to the reticulated structure of the Albian genus Favusella of Michael (1972). Morphologically the specimens of Hedbergella hoterivica from Site 397 display a moderately low trochospiral test with two-and-a-half whorls of globular chambers. The spiral side is somewhat convex; the ventral convex side shows four visible chambers which rapidly increase in size and have a reduced umbilical area, as well as a large primary arch-shaped aperture (Plate 3, Figure 4). Most of the specimens on the umbilical side contain a small bulla-like fifth or last chamber, with an extra-umbilical aperture covering the entire umbilicus and primary aperture. Through the 
LOWER CRETACEOUS FORAMINIFERAL BIOSTRATIGRAPHY, PALEOECOLOGY, AND DEPOSITIONAL ENVIRONMENT

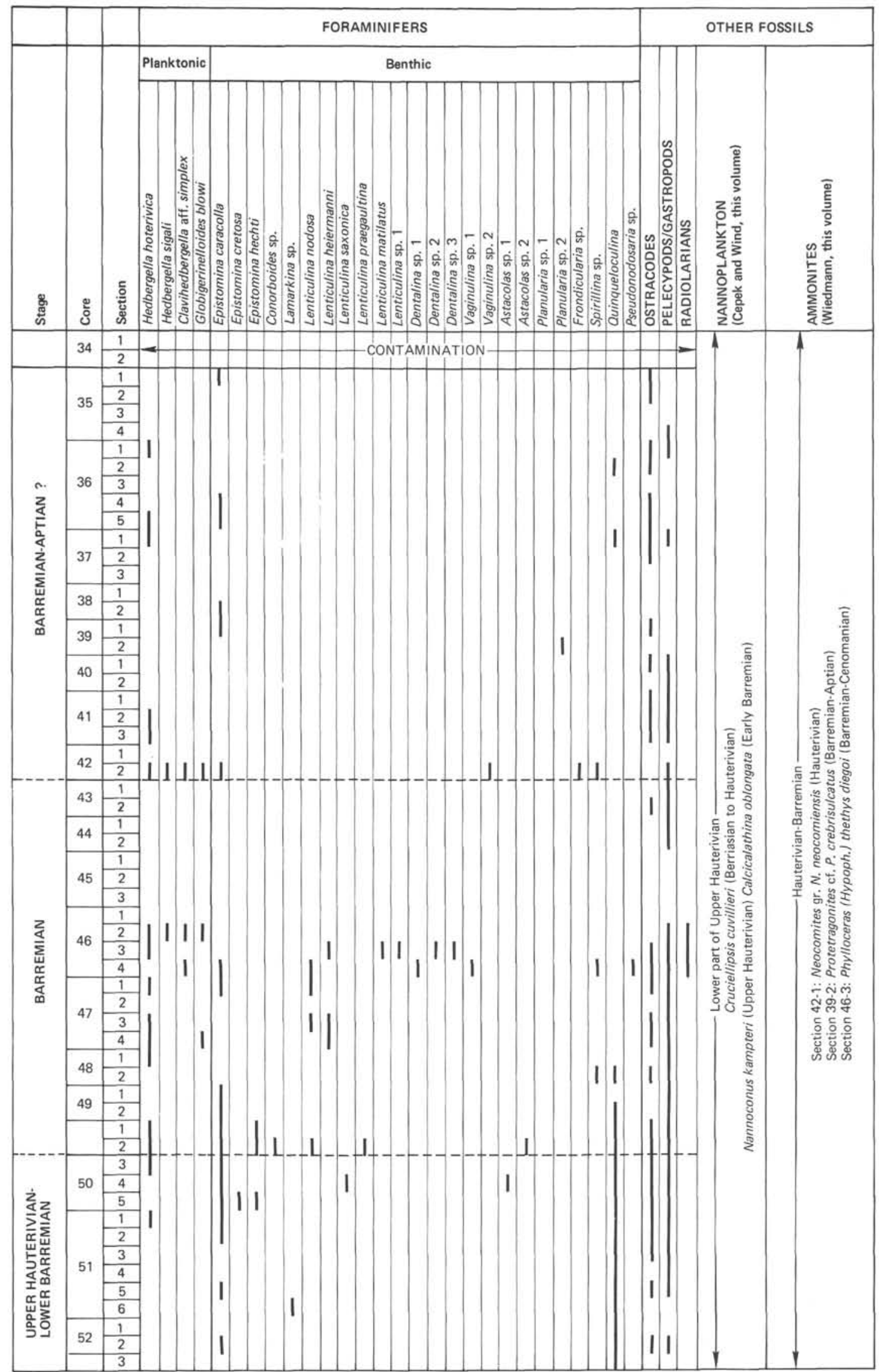

Figure 1. Distribution of Lower Cretaceous microfossils at Site 397. 
light microscope, the calcareous wall of the specimens shows fine pores giving the impression of a smooth surface; but, through SEM study, the specimens reveal a coarse reticulate honeycomb sculpture with 3 to 4 (or more) pores in each polygonal structure (Plate 4, Figures 2 and 6), resembling the genus Favusella of Michael (1972). On the basis of these characters Roesler et al. (this volume) called these specimens as new species: Favusella stiftia. The specimens also show weak to strong coarsening of the ornamentation (Plate 4), though some specimens display various destroyed stages of the reticulated shell wall (Plate 3, Figures 5 and 6). Still others consist only of calcareous casts (Plate 3, Figure 7). The test wall similarity of Hedbergella hoterivica with Favusella confirms the earlier opinion of Bolli (1959) and Bandy (1967) that Globigerina kugleri (here named Hedbergella hoterivica) gave rise to the Albian Globigerigerina washitensis (renamed by Michael, 1972, Favusella washintensis type species of the genus Favusella) by developing a high spire, adding one more chamber in the last whorl, increasing in size, and developing a honeycomb sculpture. In view of the above morphologic affinity, it is not necessary to revise this species nor to erect a new one since the coarse sculpture may not be visible, under the light microscope, and the surface ornamentation often is not preserved leaving behind a calcareous mold or cast (compare Plate 3, Figure 7). Moreover, the global appearance of the genus Favusella also seems questionable. For instance, Ascoli (1976) reported Favusella aff. washitensis from Aptian sediments in the Scotian Shelf of northwestern Atlantic. It is interesting to note that Ascoli's figure of Caucasella hoterivica from the Valanginian (pl.1., fig. 3C of Ascoli, 1976) shows a coarse reticulated structure of the shell wall. This suggests that Hedbergella hoterivica is probably an ancestor of the so-called genus Favusella, and may be regarded as "prae Favusella" (Koch, personal communication).

\section{PALEOECOLOGY AND DEPOSITIONAL ENVIRONMENTS}

The general scarcity of microfossils in the Lower Cretaceous sediments at Site 397 caused confusion regarding their paleobathtmetry. Two main views about the paleoenvironments have been presented: (1) paucity of the fossils indicates depths below the CCD, and (2) an expanded oxygen-minimum zone and stagnation of the bottom waters eliminated benthic life. Alternatively, based on the foraminiferal association, an outer shelf, upper bathyal depth range is suggested for the deposition of the Lower Cretaceous sediments. The sediments accumulated as a distal delta facies (Einsele and von $\mathrm{Rad}$, this volume). This indicates a continuous high rate of terrigenous input (cyclic sedimentation), resulting in a scarcity of nutrients and biogenic calcite in the basin. Scruton (1955) noticed a scarcity of foraminifers $(0.9 \%)$ in the modern prodelta sediments of the Mississippi Delta, where the dominant sediment components ac- companying the fraction were mainly terrigenous sand and plant fragments. ${ }^{1}$

Miliolids such as Quinqueloculina, together with ostracodes, small gastropods, and pelecypods (Figure 1); Plate 1, Figures 24 to 27; Plate 2, Figures 13 to 17, 21, and 22), suggest proximity of the near-shore shelf environment. Barren samples usually contain abundant terrigenous quartz and occasionally broken shell fragments. These constituents may suggest relatively higher rates of sedimentation, possibly related to climatic fluctuations on the nearby continent. The samples containing abundant foraminifers may represent periods of slow quiescent sedimentation, with an attendant environment of normal salinity, temperature, and an oxygenated bottom. The ostracode assemblage (Plate 2) exhibits a morphologic affinity with neritic assemblages reported from various land sections (e.g., see Brenner and Oertli, 1976). These ostracodes (Brenner and Oertli, 1976) are associated with foraminifers such as Lenticulina heiermanni and Epistomina caracolla as found in Cores 52 to 35.

Epistominids (such as Epistomina caracolla) and nodosariids (such as Lenticulina, Astacolus, Planularia, etc.) may suggest an outer-shelf upper bathyal environment. Epistomina caracolla seems to be a homeomorph of a recent species: Hoeglundina elegans. According to Bandy (1967), this is an important isobathyal species which typically occurs at the shelf edge extending down to bathyal depths. Comparing the habitat of the Cretaceous foraminifers with recent homeomorphs, Sliter (1972) suggested that an outer-shelf assemblage is represented by nodosariids and Hoeglundina, though several genera such as Gyroidina (which Sliter included in the outer-shelf range) are not known globally in Lower Cretaceous sediments. The hedbergellids and globigerinellids at Site 397 may indicate epipelagic activity of a shelf water mass. In the study of the genus Favusella, Michael (1972) pointed out that this genus is usually reported in neritic deposits. Butt (in Wiedmann et al., 1978) reported Favusella (as Hedbergella washitensis) in Albian-Cenomanian shelf deposits of AgadirEssaouira coastal sediments. It is concluded, therefore that Hedbergella hoterivica showing an affinity to Favusella may represent a pelagic shelf association.

\section{ONSHORE AND OFFSHORE CORRELATION}

\section{Tarfaya-Aaiun Region}

In contrast to the offshore prodelta facies at Site 397, the onshore Barremian-Aptian sediments from the Tarfaya-Aaiun region and a commercial well offshore from the Spanish Sahara represent a more than

\footnotetext{
'In view of age determination of the Lower Cretaceous strata at Site 397 , the author prefers to retain the name of the illustrated specimens (Plates 3,4 ) as $H$. hoterivica; however, it is likely that these specimens represent a subspecies of $H$. hoterivica bearing reticulated structures.
} 
1200-meter-thick clastic sequence of a deltaic complex (CONOCO, 1969; Wiedmann et al., 1978; Einsele and von Rad, this volume). These sediments contain rare microfossils. The fauna consists mainly of ostracodes, pelecypods, gastropods, and echinoids. Lituolids (such as Choffatella decipiens) are the only representative foraminifers mentioned in the unpublished data of CONOCO (1969). This onshore faunal association represents lagoonal to outer littoral environments relative to the offshore distal delta facies. Farther east, the landward outcrop data from the Tarfaya-Aaiun region indicates a lithofacies relation to sediments cored in the CONOCO well, representing fluviatile, lagoonal, and tidal deposits (Wiedmann et al., 1978). There, Aptianlower Albian faunas consist mainly of abundant ostracodes and small mollusks. Foraminifers include agglutinated benthics such as Trochammina and Haplophragmoides. This faunal association provides evidence for a relative low salinity lagoonal environment in the Tarfaya-Aaiun onshore deltaic system. The abovementioned Lower Cretaceous sediments, representing a shallow marine depositional environment, grade upward into a fine-grained sequence of hemipelagic sediments with interbedded shell beds in the AlbianCenomanian. Overlying eupelagic sediments display laminated chert layers in the upper CenomanianTuronian (Wiedmann et al., 1978). Biogenic components of the sedimentary succession suggest a gradual paleodepth increase, indicating submergence of the continental margin under deeper water during the Middle Cretaceous.

\section{Agadir-Essaouira Region}

In contrast to the Tarfaya-Aaiun region, the Lower Cretaceous sediments of the Agadir-Essaouira region display an intertonguing of marine and non-marine sediments. Continental facies (such as clastic sediments and red beds) and marine shelf facies (such as silty marls and shell beds) reveal several regressive and transgressive episodes. Following Upper Jurassic shallow-water carbonate sedimentation, the Agadir and Essaouira basins subsided to a relative deep shelf environment. Faunal associations represent diverse, abundant, and large nodosariids, including Lenticulina nodosa, Lenticulina eichenbergi, Lenticulina guttata, Lenticulina ouachaensis, Planularia crepidularis, Vaginulina schreiteri, etc. Epistominas (such as Epistomina coracolla), agglutinants (such as lituolids), and ostracodes frequently occur (Butt, in Wiedmann et al., 1978). This faunal association indicates an ecologic affinity with the foraminifers at Site 397. During the middle Hauterivian, the Agadir and Essaouira basins were marked by a local regression. In particular, the Essaouira Basin contains a red bed facies, comprising abundant brackish water foraminifers (Ammobaculites-Haplophragmoides).

During the late Hauterivian-Barremian, marine shelf conditions again prevailed, while the ecological spectrum is mainly represented by nodosariids as mentioned above. In particular, the Barremian sediments consist of relatively diverse planktonic foraminifers (such as Hedbergella infracretacea and Hedbergella signali), in- dicating biostratigraphic and paleoecologic affinities with the offshore fauna at DSDP Sites 397 and 370 . But, during late Barremian-early Aptian, the coastal basins record another regression. Biocomponents such as charophytes, ostracodes, and agglutinated foraminifers there may indicate shallow marine to brackish environments (lagoonal-littoral zone) and a related lowering of sea-level. The upper Aptian-Albian sediments in the Agadir and Essaouira basins mark the beginning of a Middle Cretaceous transgression that later reached a maximum during the Turonian in both onshore basins. However, local shallowing trends (see bathymetric curves in Wiedmann et al., 1978) during the late Albian and late Cenomanian in the Agadir Basin and late Albian through Cenomanian shallowing (calcareous platform sedimentation) in the Essaouria Basin may suggest lateral bathymetric variations in the local coastal basins.

\section{Discussion of Results}

Onshore Lower Cretaceous sediments in both the Agadir-Essaouira and the Tarfaya-Aaiun regions reveal marine and non-marine sedimentary sequences. These facies display a deltaic character and can be correlated in terms of foraminiferal ecology and biostratigraphy with the offshore distal delta facies described as "turbidites" or "laminates" at DSDP Sites 370 and 397. In contrast to present depths at Sites 370 and 397, which are approximately 4000 and 3000 meters, respectively, the Lower Cretaceous foraminiferal association indicates a shallower paleodepth in a marginal setting of the eastern North Atlantic. These are possibly equivalent to outer-shelf and upper bathyal water depth levels $(500 \mathrm{~m})$. During the Middle Cretaceous, however, the offshore depositional sites probably subsided rapidly to bathyal-abyssal depth levels. Interestingly, this subsidence of the sea floor correlates with a synchronous Middle Cretaceous transgression and a related eustatic sea-level rise in the onshore basins (compare Sliter, 1976), eliminating the Lower Cretaceous shallow-water deltaic environments along the ancient coasts.

\section{ACKNOWLEDGMENTS}

I appreciate stimulating discussions with Drs. J. Wiedmann, G. Einsele, U. Pflaumann, G. Lutze, and W. Roesler. I am particularly grateful to Dr. U. von Rad for encouraging me to present this paper to the DSDP Initial Reports. Many thanks are owed to Dr. J. P. Beckmann for reviewing my manuscript. Mr. H. Hüttemann assisted in preparing scanning electron photographs of the foraminifers. Thanks are due to Beate Döttling for typing the final version of the manuscript and to the Deutsche Forschungsgemeinschaft, Bonn, for providing funds.

\section{REFERENCES}

Ascoli, P., 1976. Foraminiferal and ostracod biostratigraphy of the Mesozoic-Cenozoic, Scotian Shelf, Atlantic CanadaMaritime Sediments, First Symposium on Benthonic Foraminifera of Continental margins, part B, p. 653-771.

Bandy, O., 1967. Benthonic foraminifera as environment indices American Geological Institute, Paleoecology, lecture 6 OB-1B-OB-29B.

Bartenstein, H., 1976. Micropaleontological investigations, Erdöl und Kohle, v. 29, p. 254-256. 
Bolli, H. M., 1959. Planktonic foraminifera from the Cretaceous of Trinidad, B. W., Bull. Am. Paleontol., v. 139 , p. $257-277$.

Brenner, P. and Oertli, J., 1976. Lower Cretaceous ostracods Valanginian to Hauterivian) from the Sundays River formation Algola Basin, South Africa, Bull. Centre Rech. Pau-SNPA, v. 10, p. 471-533.

Butt, A., in Wiedmann, J. et al., 1978. Vergleich von Marok kanischen Kreide-Kustenauschlussen und Tiefseebohrungen (DSDP): Stratigraphie, Paleoenvironment und Subsidence an einem passiven Kontinentalrand, Géol. Rundschau., v. 67, p. 450-508.

CONOCO, 1969. Well Spansah 51A-1, offshore Spanisch Sahara, paleontological final report by Continental Oil Company of Spain, Spanisch Gulf Oil Company, Company Español de Petroleas S. A., Exploration Department, Unpublished report and logs.

Dailey, D. H., 1973. Early Cretaceous foraminifera from the Budden Canyon Formation, northwestern Sacramento Valley, California, Univ. California Publications in Geological Sciences, v. 106, p. 1-111.

Fuchs, W., 1971. Eine alpine Foraminiferenfauna des tieferen Mittel-Barrême aus den Drusberg-schiechten vom Ranzenberg bei Hohenens in Vorarlberg (Österreich), Abh. Geol. Bundesanstalt, v. 27, p. 49.

Michael, E., 1967. Die Mikrofauna des nw.-deutschen Bar rême, Palaeontographica, v. 12, p. 1-176.
Michael, F. Y., 1972, Planktonic foraminifera from the Commanchean Series (Cretaceous) of Texas, J. Foram. Res., v.2, p. $200-220$.

Moullade, M., 1966. Etude Stratigraphique et Micropaléon tologique du Cretace Inférieur de la "Fosse Vocontienne," Doc. Lab. Geol. Fac. Sci. Lyon, no. 15, p. 369.

Scruton, P. C., 1955. Sediments of the eastern Mississippi Delta, Soc. Econ. Pal. Min., Spec. Publ. 3, p. 21-51.

Sliter, W. V., 1972. Cretaceous foraminifera-depth habitat and their origin, Nature, v. 239, p. 514-515.

,1976. Cretaceous foraminifera from the southwestern Atlantic Ocean Leg 36, Deep Sea Drilling Project. In Barker, P., Dalziel, I. W. D., et al., Initial Reports of the Deep Sea Drilling Project, v. 36; Washington (U. S. Government Printing Office), p. 519-573.

Subbotina, N. N., 1953. Globigerinidy, Hantkeninidy i Globorotaliidy-Isokopaemye foraminifera SSSR, Trudy Vnigri, nov. serv., v. 76, p. 296.

van Hinte, J. E., 1976, A Cretaceous time scale, Am. Assoc. Petrol. Geol. Bull., v. 60, p. 498-516.

Wiedmann, J., Butt, A., and Einsele, G., 1978. Vergleich von Manokkanischen Kreide-Aufschlüssen und Tiefseebohrungen (DSDP): Stratigraphie, Paläoenvironment und Subsidence an einem passiven Kontinentalrand, Geol. Rundschau., v. 67, p. 450-508. 
PLATE 1

Figure $1 \quad$ Spirillina sp.; Sample 42-2, 5-10 cm $(150 \times)$.

Figure 2 Dentalina sp. 1; Sample 46-4, 80-84 cm $(100 \times)$.

Figure 3 Dentalina sp. 2; Sample 46-3, 50-55 cm $(50 \times)$.

Figure $4 \quad$ Vaginulina sp. 2; Sample 42-2, 5-100 cm $(150 \times)$.

Figure 5 Dentalina sp. 3; Sample 46-3, 50-55 cm $(50 \times)$.

Figure 6 Astacolus sp. 1; Sample 60-4, 95-100 cm $(100 \times)$.

Figure $7 \quad$ Astacolus sp. 2; Sample 50-2, 15-19 cm $(150 \times)$.

Figure $8 \quad$ Vaginulina sp. 1; Sample 46-4, $50-55 \mathrm{~cm}(75 \times)$.

Figure 9 Astacolus sp. 3; Sample 50-1, 114-119 cm $(100 \times)$.

Figure $10 \quad$ Planularia sp. 2; Sample $39-2,44-47 \mathrm{~cm}(75 \times)$.

Figure 11 Planularia sp. 1; Sample 46-4, 80-84 cm $(150 \times)$.

Figure 12 Frondicularia sp.; Sample 42-2, 49-51 cm $(150 \times)$.

Figure 13 Lenticulina nodosa (Reuss) aff. Lenticulina busnardoi Moullade; Sample 50-2, 0-6 cm $(75 \times)$.

Figure $14 \quad$ Lenticulina sp. cf. Lenticulina nodosa (Reuss), Sample 47-1, 10-14 $\mathrm{cm}(100 \times)$.

Figure 15 Lenticulina heiermanni Bettenstaedt; Sample 47-3, 25-28 cm $(100 \times)$.

Figure 16 Lenticulina heiermanni Bettenstaedt aff. Lenticulina roemeri (Reuss) Moullade 1966; Sample 47-4, 51-55 cm $(75 \times)$.

Figure 17 Lenticulina nodosa (Reuss); Sample 47-1, 80-83 cm $(75 \times)$.

Figure 18 Lenticulina saxonica Bartenstein and Brand; Sample 50-4, 95-100 $\mathrm{cm}(50 \times)$.

Figure 19 Lenticulina matilatus (Espitalié and Sigal); Sample 46-3, 145-149 $\mathrm{cm}(75 \times)$.

Figure $20 \quad$ Lenticulina sp. 1; Sample 46-3, 50-55 cm $(100 \times)$.

Figure 21 Lenticulina praegaultina Bartenstein, Bettenstaedt and Bolli; Sample $50-2,0-6 \mathrm{~cm}(100 \times)$.

Figure 22 Ramulina sp.; Sample 46-3, 50-55 cm $(75 \times)$.

Figure 23 Pseudonodosaria sp.; Sample 46-4, 0-5 cm $(150 \times)$.

Figures 24-27 Miliolids

24. Quinqueloculina sp.; Sample 50-3, 130-135 cm $(150 \times)$.

25. Quinqueloculina sp.; Sample 48-2, 30-35 cm $(150 \times)$.

26. Quinqueloculina sp.; Sample 50-3, 0-6 cm $(150 \times)$.

27. Quinqueloculina sp.; Sample $50-4,145-150 \mathrm{~cm}(150 \times)$. 
PLATE 1

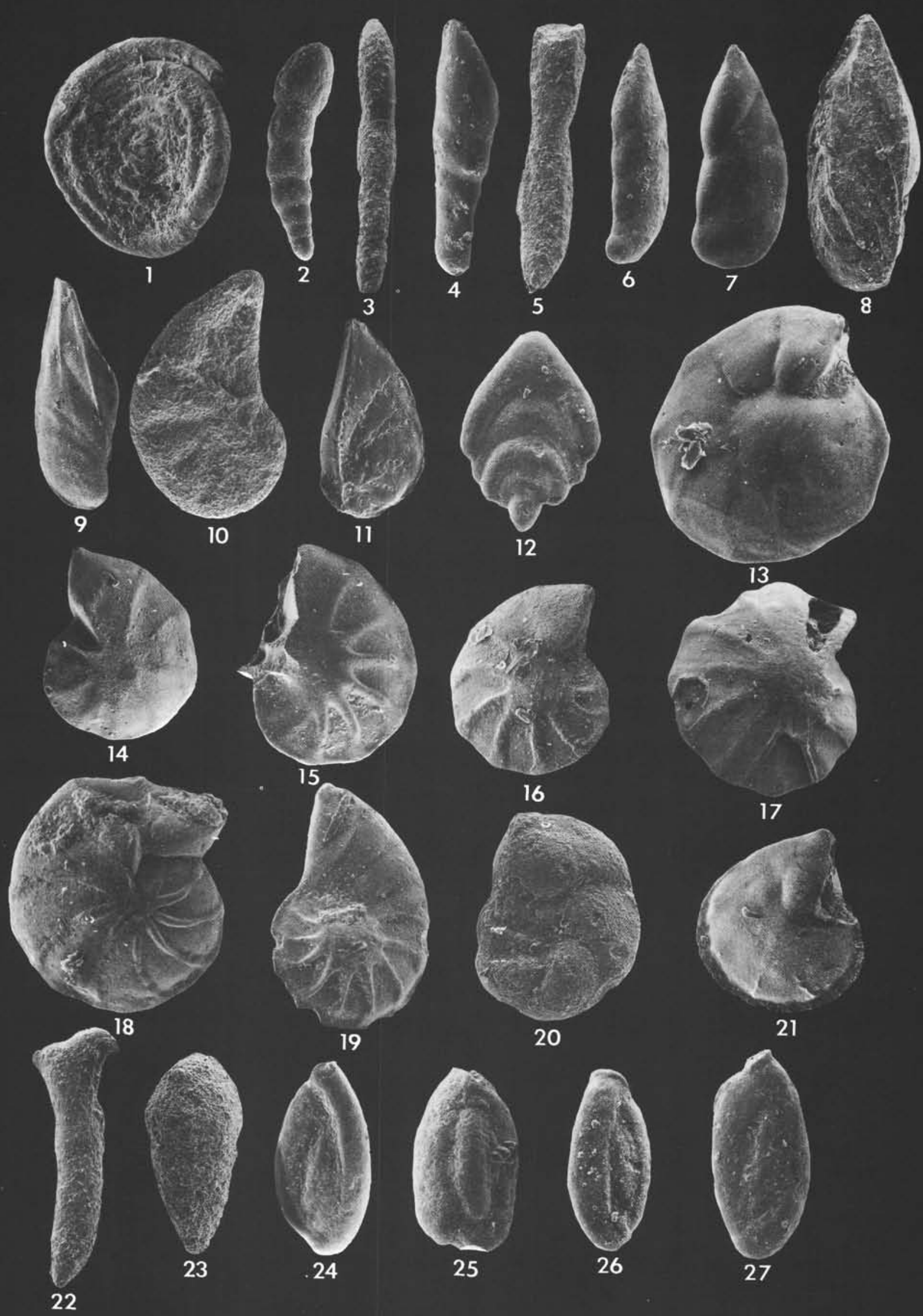




\section{PLATE 2}

Figure 1 Quinqueloculina sp. showing enlargement of the apertural area; Sample 50-3, 130-135 cm $(925 \times)$.

Figure 2 Epistomina caracolla (Roemer) ventral view; Sample 50-4, 145-150 $\mathrm{cm}(100 \times)$.

Figure 3 Epistomina caracolla (Roemer) dorsal view; Sample 46-3, 100-104 $\mathrm{cm}(100 \times)$.

Figure $4 \quad$ Epistomina hechti Bartenstein, Bettenstaedt and Bolli; dorsal view; Sample 50-2, 0-6 cm $(115 \times)$.

Figure 5 Epistomina caracolla (Roemer); ventral view (pyritized shell); Sample 46-3, 100-104 cm $(100 \times)$.

Figure 6 Epistomina sp.; ventral view; Sample 50-4, 95-100 cm $(150 \times)$.

Figure 7 Epistomina hechti Bartenstein, Bettenstaedt, and Bolli; dorsal view; Sample 50-5, 21-25 cm $(100 \times)$.

Figure $8 \quad$ Epistomina cretosa Ten Dam; dorsal view (compare Ascoli, 1976); Sample 50-5, $21-25 \mathrm{~cm}(150 \times)$.

Figure 9 Conorboides sp.; dorsal view; Sample 50-2, 0-6 cm $(150 \times)$.

Figure 10 Epistomina sp.; ventral view; Sample 50-1, 80-85 cm $(150 \times)$.

Figure 11 Ostracode; Sample 50-1, 80-85 cm $(75 \times)$.

Figure 12 Epistomina ornata (Roemer) ?; Sample 50-1, 114-119 cm $(150 \times)$.

Figures 13-17 Ostracodes (neritic assemblage compare Brenner and Oertli, 1976).

13. Orthonotacythere ?; Sample 50-4, 95-100 cm $(100 \times)$.

14. Centrocythere bordeti Demotte and Grosdidier?; Sample 50-4, $145-150 \mathrm{~cm}(50 \times)$.

15. Acrocythere ?; Sample 41-2, 105-109 cm $(100 \times)$.

16. Cythereis ?; Sample 50-4, 145-150 cm $(50 \times)$.

17. Schuleridea sp. ?; Sample 50-2, $15-19 \mathrm{~cm}(50 \times)$.

Figure 18 Fish otolith; Sample 43-3, 25-30 cm $(150 \times)$.

Figures 19, 20 Radiolarian specimens; Sample 46-3, 100-104 cm.

19. $(150 \times)$.

20. $(150 \times)$.

Figure 21 Micro-gastropod; Sample 47-3, 80-84 cm $(150 \times)$.

Figure 22 Micro-pelecypod; Sample 50-2, 0-6 cm $(100 \times)$.

Figure 23 Coccoliths attached to the shell wall of a planktonic foraminiferal chamber; Sample 46-3, 145-149 cm (3250×). 
PLATE 2

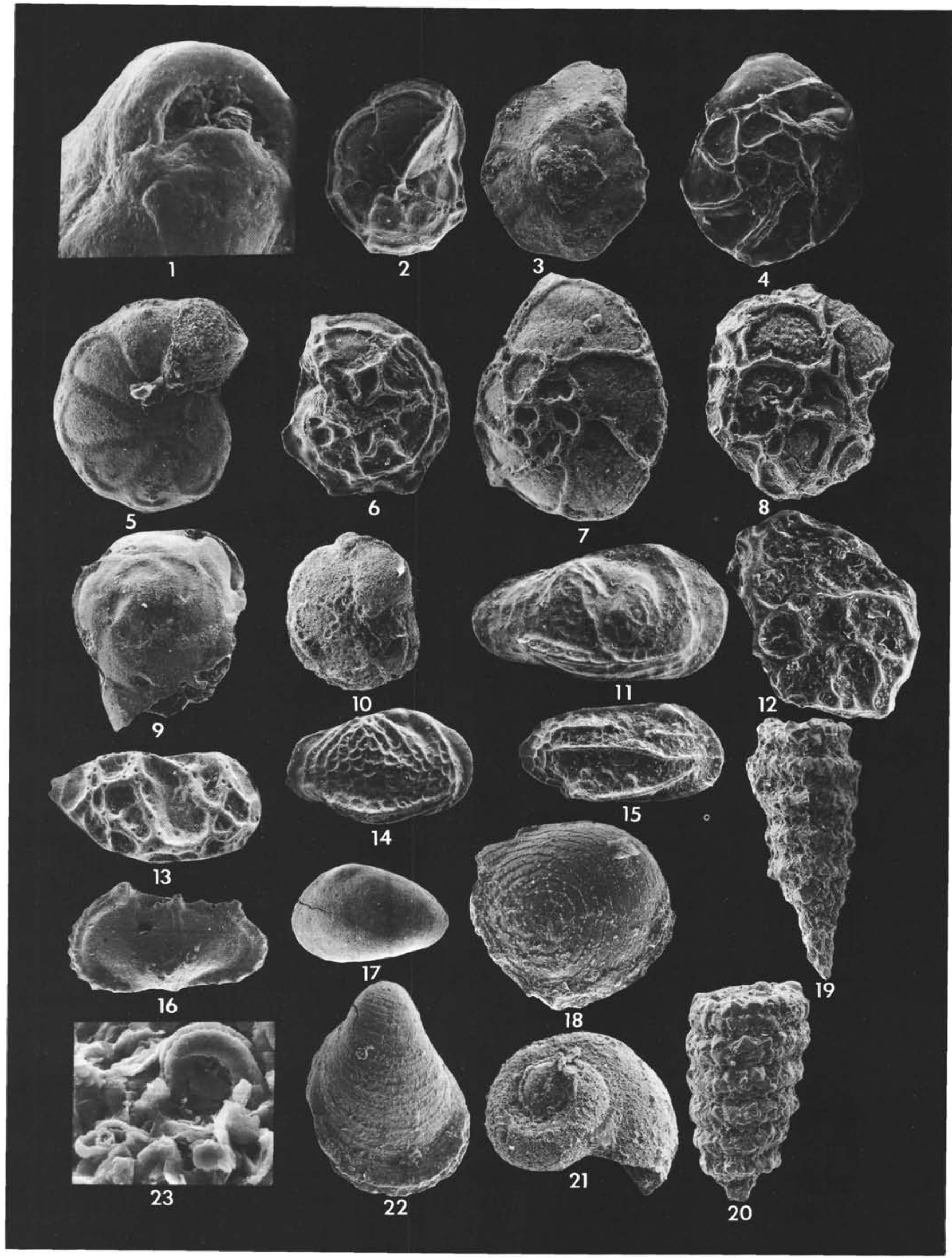




\section{PLATE 3}

Figures 1, 2 Hedbergella hoterivica (Subbotina); Sample 50-1, 80-85 cm.

1. Spiral view $(250 \times)$.

2. Detail of the test wall $(1500 \times)$.

Note polygonal structures; pores are not visible.

Figure 3 Hedbergella hoterivica (Subbotina); umbilical view, showing small bulla-like chamber; Sample 46-3, 145-149 cm $(250 \times)$.

Figure 4 Hedbergella hoterivica (Subbotina); umbilical view; showing primary umbilical aperture; Sample 47-3, 23-26 cm (250×) (compare Ascoli, 1976).

Figures 5, 6 Hedbergella hoterivica (Subbotina); Sample 47-4, 51-55 cm.

5 . Spiral view, showing diagenetic destruction of the reticulated wall $(250 \times)$.

6. Detailed view of the shell wall as in Figure $5(2500 \times)$.

Figure $7 \quad$ Hedbergella hoterivica (Subbotina); spiral view showing complete removal of the reticulated shell wall (Steinkern). This specimen resembles some land specimens of $H$. hoterivica showing smooth surface; Sample 46-2, 100-105 cm $(250 \times)$.

Figure $8 \quad$ Hedbergella sp.; Sample 42-2, 5-10 cm $(250 \times)$.

Figure 9 Hedbergella sigali Moullade; spiral view; Sample 46-2, 101-105 cm $(250 \times)$.

Figure $10 \quad$ Hedbergella sigali Moullade; spiral view; Sample 42-2, 5-10 cm $(200 \times)$.

Figure 11 Clavihedbergella aff. simplex (Morrow); spiral view; Sample 42-2, $5-10 \mathrm{~cm}(200 \times)$.

Figure 12 Clavihedbergella aff. simplex (Morrow); spiral view; Sample 46-2, $101-105 \mathrm{~cm}(250 \times)$.

Figure 13 Clavihedbergella sp.; spiral view; Sample 46-4, 80-84 cm $(375 \times)$.

Figure 14 Globigerinelloides blowi (Bolli); side view; Sample 42-2, 5-10 cm $(200 \times)$.

Figure 15 Globigerinelloides blowi (Bolli); peripheral view; Sample 42-2, 5-10 $\mathrm{cm}(200 \times)$.

Figure 16 Globigerinelloides blowi (Bolli); side view; Sample 42-2, 5-10 cm $(200 \times)$.

Figure 17 Globigerinelloides blowi (Bolli); side view; Sample 42-2, 5-10 cm $(200 \times)$. 


\section{PLATE 3}
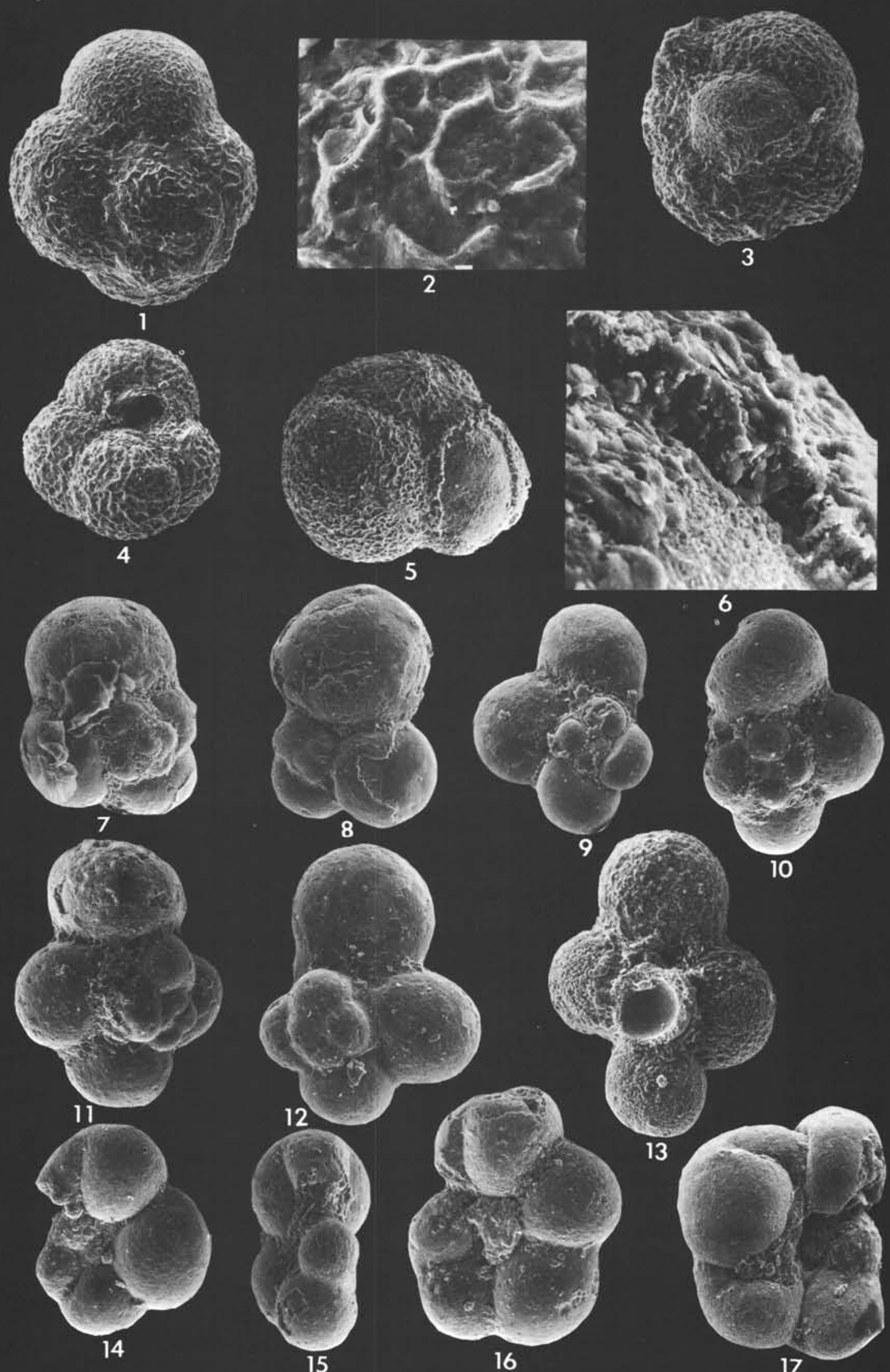

16
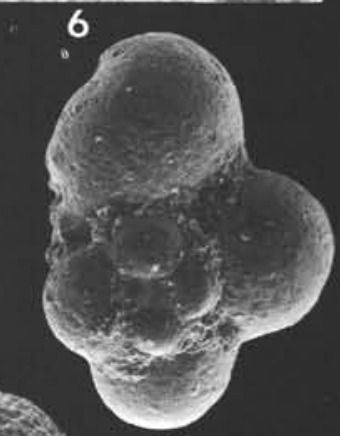
PLATE 4

Figures 1, 2 Hedbergella hoterivica (Subbotina), showing similarity of the ultrastructure with genus Favusella of Michael (1972); Sample 47-1, 10-14 cm.

1. Umbilical view; note bulla-like last chamber covering the umbilicus $(350 \times)$.

2. Details of the shell wall; note polygonal structure with small pores $(350 \times)$.

Figures 3, 4 Hedbergella hoterivica (Subbotina); Sample 47-3, 23-26 cm.

3. Umbilical view; note the last reduced chamber shows a lip-like extension, covering the primary umbilical aperture $(350 \times)$.

4. Umbilical details as in Figure $3(1400 \times)$.

Figures 5, 6 Hedbergella sp. aff. H. Hoterivica (Subbotina); Sample 46-2, 101-105 cm.

5. Spiral view $(200 \times)$.

6. Micro-details of the shell wall as in Figure 5; note a lesser coarsening of the polygonal structures than in Figures 1 to 4 , above $(3500 \times)$. 


\section{PLATE 4}
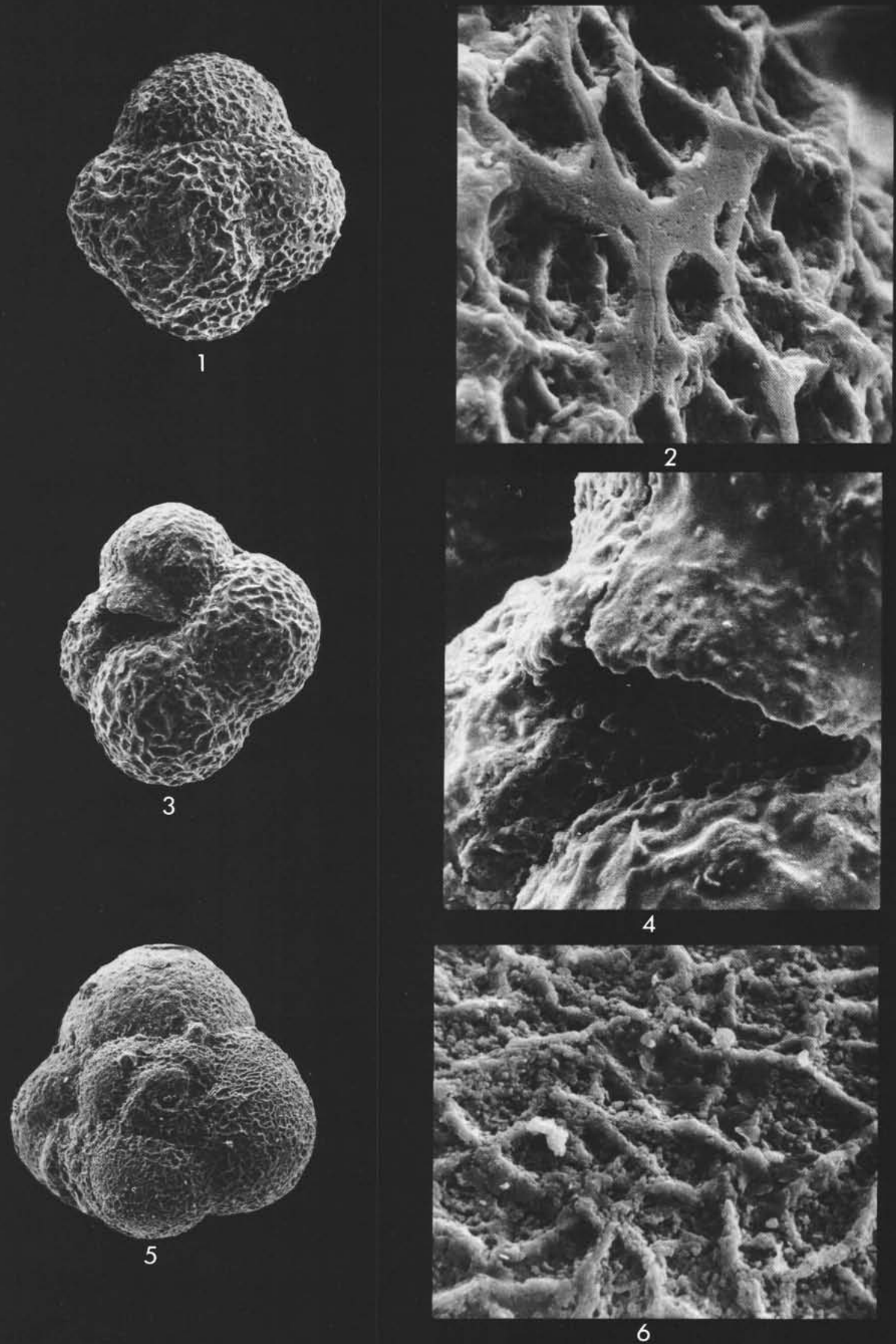